\title{
PREDIKSI PENURUNAN MUKA TANAH MELALUI PENDUGAAN POTENSI AIR TANAH MENGGUNAKAN METODE SELF-POTENTIAL
}

\author{
Fajriani $^{1, a}$, Teuku Andi Fadlly,b, Tisna Harmawan ${ }^{3, c}$ \\ ${ }^{1,2,3}$ Universitas Samudra \\ e-mail: $\underline{\text { afajriani@unsam.ac.id, }}$ bandifadly@unsam.ac.id, $\underline{\text { ctisna_harmawan@unsam.ac.id }}$
}

\begin{abstract}
Abstrak
Penurunan muka tanah merupakan bencana geologi berupa turunnya permukaan tanah yang terjadi secara alami. Salah satu penyebab penurunan muka tanah diakibatkan oleh kegiatan eksploitasi air tanah. Di Gampong Lengkong setiap harinya aktivitas pengeboran air tanah dilakukan untuk didistribusikan ke sebagian besar masyarakat kota Langsa. Kegiatan pengeboran air tersebut dapat memicu berkurangnya potensi air tanah. Tujuan penelitian untuk mengidentifikasi potensi air tanah sebagai upaya awal memantau kondisi bawah permukaan agar penurunan tanah akibat kekosongan akuifer dapat dicegah. Pendugaan potensi air tanah tersebut, dapat dilakukan dengan menggunakan metode SelfPotential. Hasil pengukuran menunjukkan bahwa selama dua bulan pengukuran terlihat perbedaan nilai potensial yang terukur di ketiga lintasan. Interpretasi data dilakukan dengan menganalisis peta kontur isopotensial yang memberikan informasi bahwa nilai potensial di bulan kedua menjadi lebih kecil dari bulan pertama pengukuran. Perubahan nilai potensial ini diduga akibat dari perubahan potensi air tanah. Berubahnya potensi air tanah mengarah kepada pengurangan jumlah air tanah. Pengurangan air ini disebabkan oleh adanya aktivitas pengambilan air tanah yang berlebihan setiap harinya, sehingga dapat diyakini mengakibatkan berkurangnya jumlah air tanah pada lapisan akuifer. Jika jumlah air tanah dalam akuifer terus berkurang maka daya dukung tanah menjadi semakin melemah dan potensi bencana penurunan muka tanah akan semakin cepat terjadi.
\end{abstract}

Kata kunci: penurunan muka tanah, self-potential, lengkong

\section{PREDICTION OF SOIL SUBSTANCE THROUGH THE ESTIMATION OF GROUNDWATER POTENTIAL USING THE SELF-POTENTIAL METHOD}

\begin{abstract}
Land subsidence is a geological disaster in the form of a naturally occurring land subsidence. One of the causes of land subsidence is the exploitation of groundwater. In Gampong Lengkong every day, groundwater drilling activities are carried out to be distributed to most of the people of Langsa City. These water drilling activities can trigger a reduction in groundwater potential. The purpose of this research is to identify groundwater potential as an initial effort to monitor subsurface conditions so that land subsidence due to aquifer voids can be prevented. Estimation of the groundwater potential can be done using the Self-Potential method. The measurement results show that during the two months of measurement, there are differences in the measured potential values in the three tracks. Data interpretation is done by analyzing isopotential contour maps which provide information that the potential value in the second month is smaller than the first month of measurement. This change in potential value is thought to be the result of changes in groundwater potential. Changes in groundwater potential lead to a reduction in the amount of groundwater. This water reduction is caused by excessive groundwater extraction activities every day, so it can be believed that this results in a reduced amount of groundwater in the aquifer layer. If the amount of groundwater in the aquifer continues to decrease, the carrying capacity of the soil will weaken and the potential for land subsidence will occur more quickly.
\end{abstract}

Keywords: Project-Based Learning Model, SETS Approach, Creative Thinking Ability

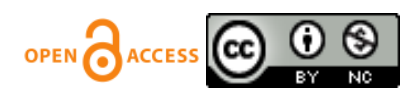




\section{PENDAHULUAN}

Bencana geologi merupakan suatu fenomena geologi yang terjadi di atas permukaan bumi yang disebabkan oleh aktivitas dari dalam bumi yang muncul ke permukaan. Bencana geologi secara umum terdiri atas bencana yang terkait dengan material geologi dan proses geologi. Salah satu bencana akibat dari proses geologi adalah penurunan muka tanah (land subsidence). Penurunan muka tanah adalah peristiwa geologi berupa turunnya muka tanah secara alami relatif terhadap suatu bidang referensi tertentu yang dianggap stabil [4]. Peristiwa penurunan muka tanah ini disebabkan oleh beberapa faktor seperti pembebanan di atas permukaan, hilangnya air tanah akibat dari eksploitasi yang berlebihan, gempa yang mengakibatkan rusaknya struktur tanah, ketidakstabilan bidang tanah akibat proses tertentu, dan lain sebagainya. Dari faktor faktor penyebab tersebut, eksploitasi air tanah yang berlebihan yang menjadi penyebab penurunan muka tanah di daerah perkotaan.

Eksploitasi air tanah secara berlebihan dan dalam waktu yang relatif lama dapat menyebabkan berkurangnya volume air tanah yang berada di lapisan akuifer (lapisan di bawah permukaan tanah yang mengandung air) tertentu. Berkurangnya air tanah ini berdampak pada kekosongan pori-pori tanah sehingga tekanan hidrostatik yang terdapat di bawah permukaan tanah akan berkurang. Hal tersebut akan berdampak pada pemampetan lapisan akuifer sehingga akan menyebabkan penurunan muka tanah.

Hampir seluruh masyarakat di berbagai wilayah memanfaatkan air tanah untuk keperluan sehari-hari, termasuk masyarakat di Kota Langsa. Pemanfaatan air tanah oleh masyarakat Kota Langsa tidak hanya melalui air PDAM tetapi juga ada yang menggunakan air bersih tambahan yang disuplai oleh distributor air bersih dari Desa Lengkong. Dari gampong tersebut air bersih diambil dari pengeboran air tanah. Apabila pengeboran air tersebut terus dilakukan maka dikhawatirkan akan terjadinya penurunan tanah lokal di gampong tersebut, melihat jumlah air yang didistribusikan ke masyarakat setiap harinya dalam jumlah yang tidak sedikit [5]. Ditambah lagi penggunaan air tanah oleh penduduk gampong lengkong dan sekitarnya melalui sumur gali dan sumur bor. Maka dari itu perlu diketahui potensi air tanah tersebut untuk melihat dan memantau kondisi akuifer air tanah di gampong lengkong untuk menghindari terjadinya penurunan tanah lokal akibat dari kosongnya pori-pori tanah karena menipisnya persediaan air tanah.

Pendugaan potensi air tanah tersebut, dapat dilakukan dengan menggunakan metode geolistrik potensial diri (Self-Potential). Metode Self-Potential (SP) merupakan salah satu metode geofisika yang dapat digunakan untuk eksplorasi dangkal seperti mendeteksi keberadaan air tanah. Metode SP ini termasuk metode geofisika pasif yang mengukur potensial alami dari bawah permukaan bumi. Potensial yang terukur dapat digunakan sebagai informasi pendugaan potensi air tanah.

Cabang ilmu pertanian juga menggunakan metode SP dalam mempelajari potensi air tanah pada lahan pertanian guna mengetahui pemanfaatan saluran waduk untuk mengevaluasi lahan perkebunan tebu sebagai penyimpan cadangan air dalam proses [3]. Interpretasi secara kualitatif dilakukan dengan menggambarkan peta isopotensial berdasarkan nilai potensial hasil pengukuran di lapangan. Sedangkan interpretasi secara kuantitatif dilakukan dengan menganggap anomali bawah permukaan model lempeng miring 2 dimensi [2].

Berdasarkan penelitian-penelitian tersebut, maka penelitian ini bertujuan untuk mengidentifikasi potensi air tanah di Gampong Lengkong berdasarkan data potensial diri yang terukur menggunakan metode self-potential. Hasil analisis berdasarkan data yang diperoleh akan digunakan untuk mengetahui potensi terjadinya penurunan muka tanah (land subsidence). Penelitian ini diharapkan mampu memberikan informasi mengenai kondisi akuifer air tanah, sebagai upaya pencegahan 
penurunan muka tanah di Gampong Lengkong, Kota Langsa.

\section{METODE}

Penelitian ini dilakukan melalui beberapa tahapan pelaksanaan, diantaranya survey lapangan untuk menentukan lokasi pengukuran, akuisisi data lapangan menggunakan metode self-potential, dan pengolahan data menggunakan beberapa Software diantaranya Microsoft Excel dan Surfer 13. Lokasi penelitian di Gampong Lengkong, Kecamatan Langsa Baro, Kota Langsa. Selanjutnya menentukan lintasan yang memungkinkan untuk dilakukan pengukuran sehingga dapat ditentukan desain survey yang tepat untuk daerah penelitian. Dipilih tiga lintasan pengukuran yang struktur permukaan tanahnya baik untuk dilakukan pengambilan data. Panjang lintasan pengukuran di semua lintasan 88 meter dengan spasi antar elektroda sebesar 4 meter. Lintasan pengukuran dapat dilihat pada gambar 1 berikut ini:

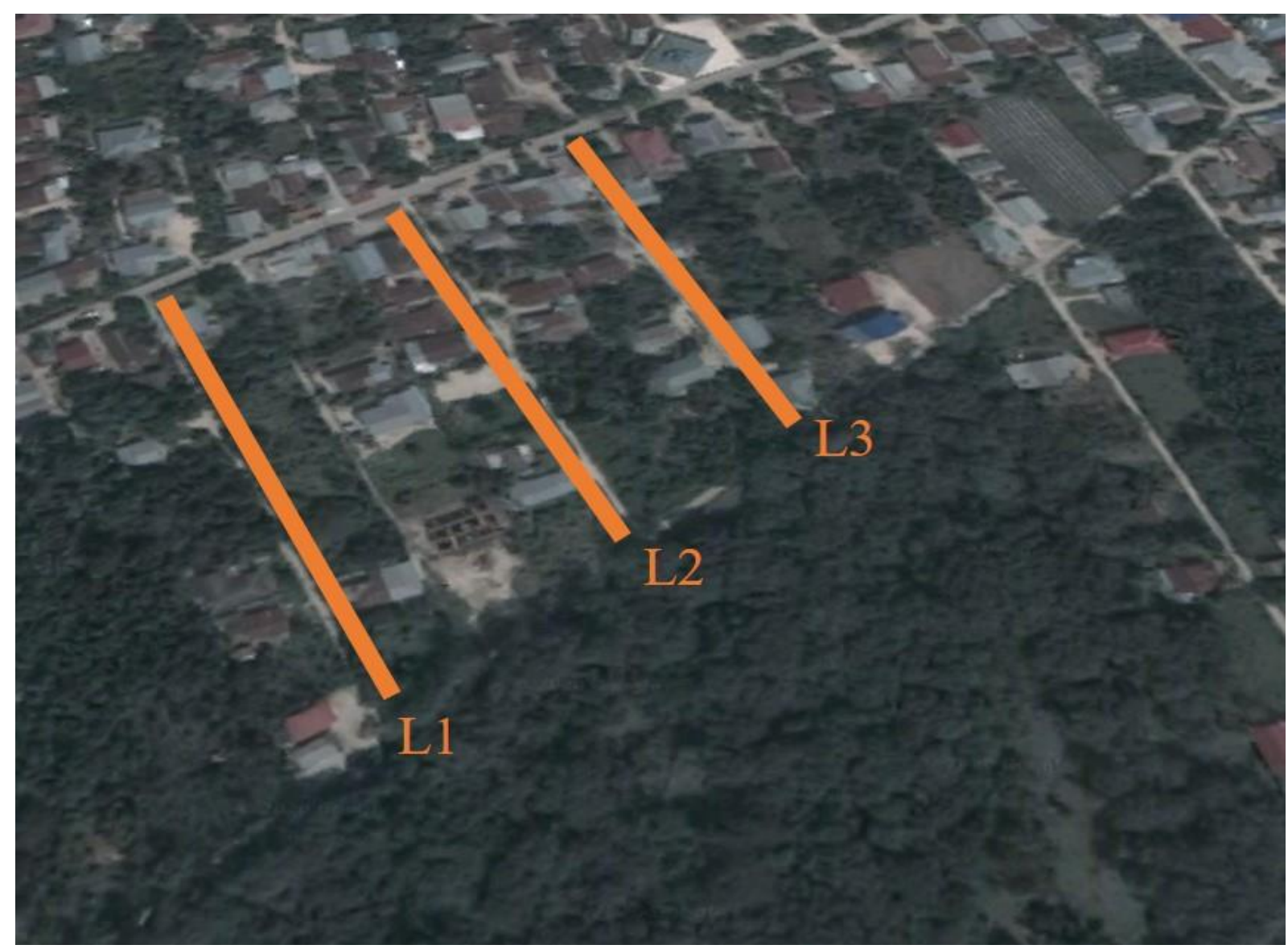

Gambar 1. Lokasi Lintasan Penelitian [1]

Akuisisi data lapangan dilakukan dalam waktu dua bulan yaitu Juli dan Agustus untuk meninjau perubahan nilai beda potensial alami bumi. Pada penelitian ini pengumpulan data dilakukan dengan menggunakan metode SP. Metode SP mengukur beda potensial bawah permukaan antara dua buah elektroda non polarisasi (porous pot) dengan teknik pengumpulan data yang digunakan yaitu teknik basis tetap (fixed base). Ciri teknik ini yaitu satu elektroda berada pada satu titik tetap (referensi) dan elektroda lainnya berpindah-pindah menjauhi titik referensi dengan interval yang tetap untuk setiap pengukuran. 
Data SP hasil pengukuran diolah untuk mendapatkan peta kontur isopotential yang menunjukkan nilai potensial alami dibawah permukaan saat pengukuran. Selanjutnya dilakukan analisis kualitatif dan perbandingan nilai potensial dalam dua pengukuran pada bulan yang berbeda. Secara sederhana alur penelitian ditunjukkan dalam diagram alir dibawah ini:

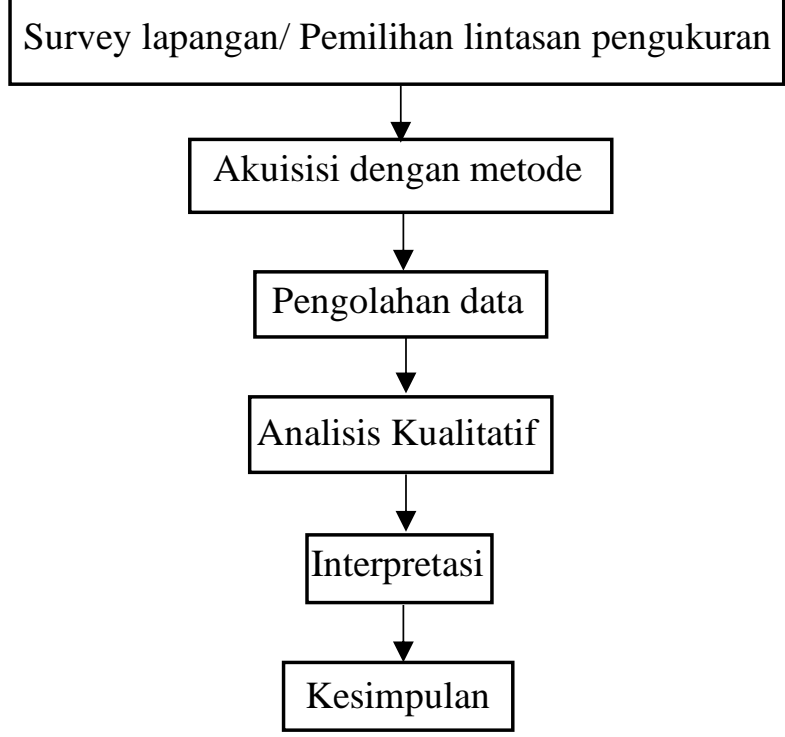

Gambar 2. Alur Penelitian

\section{HASIL DAN DISKUSI}

\section{Lintasan 1}

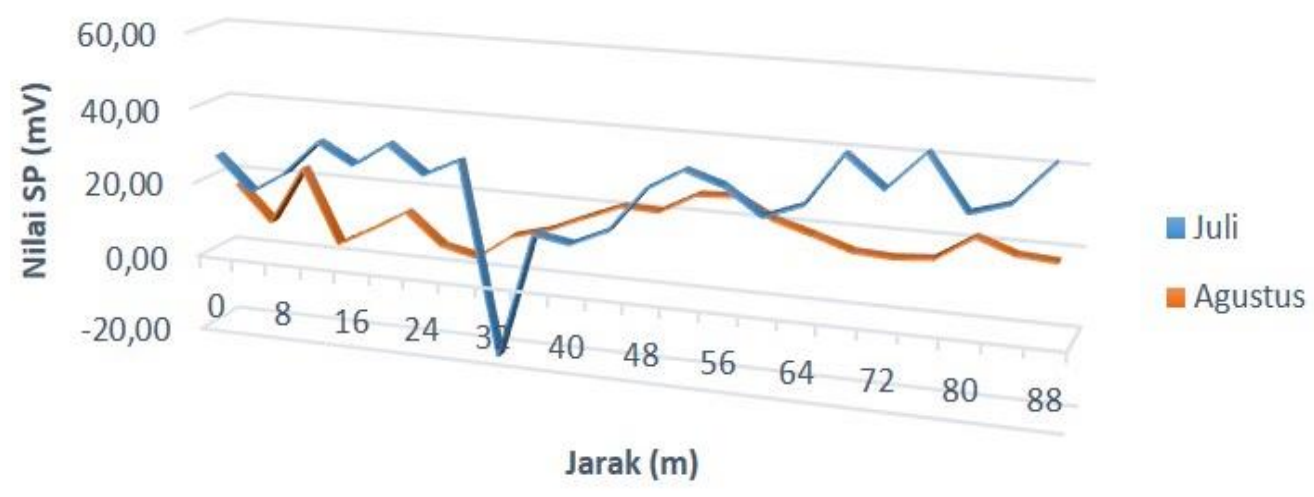

Gambar 3. Hasil Pengukuran SP di Lintasa 1 


\section{Lintasan 2}

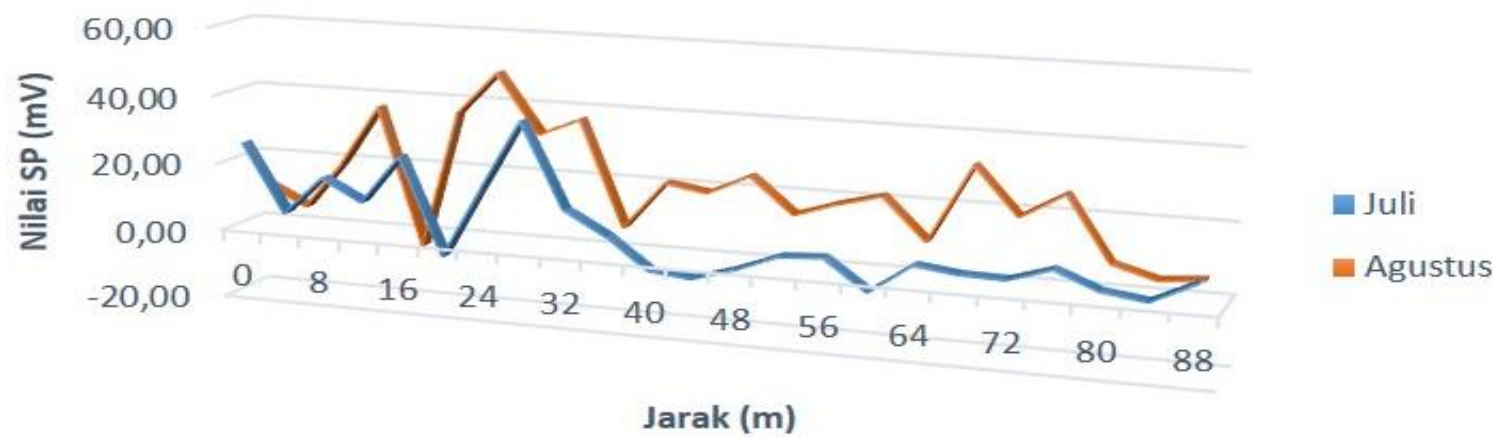

Gambar 4. Hasil Pengukuran SP Lintasan 2

\section{Lintasan 3}

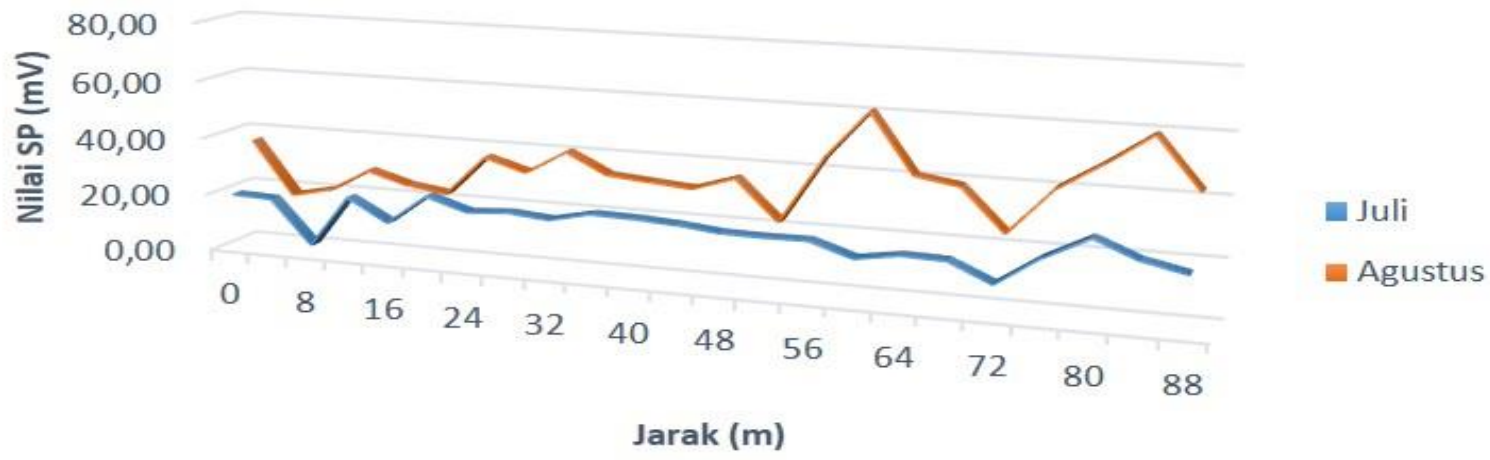

Gambar 5. Hasil Pengukuran SP Lintasan 3

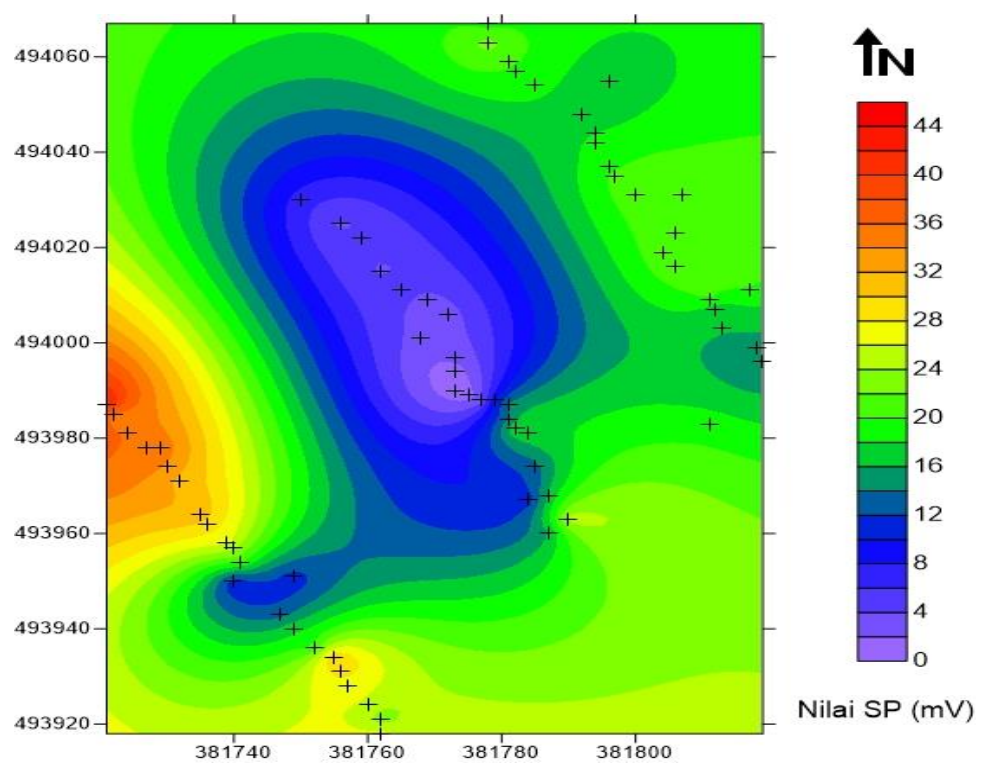

Gambar 6. Peta Kontur Isopotensial Bulan Juli 


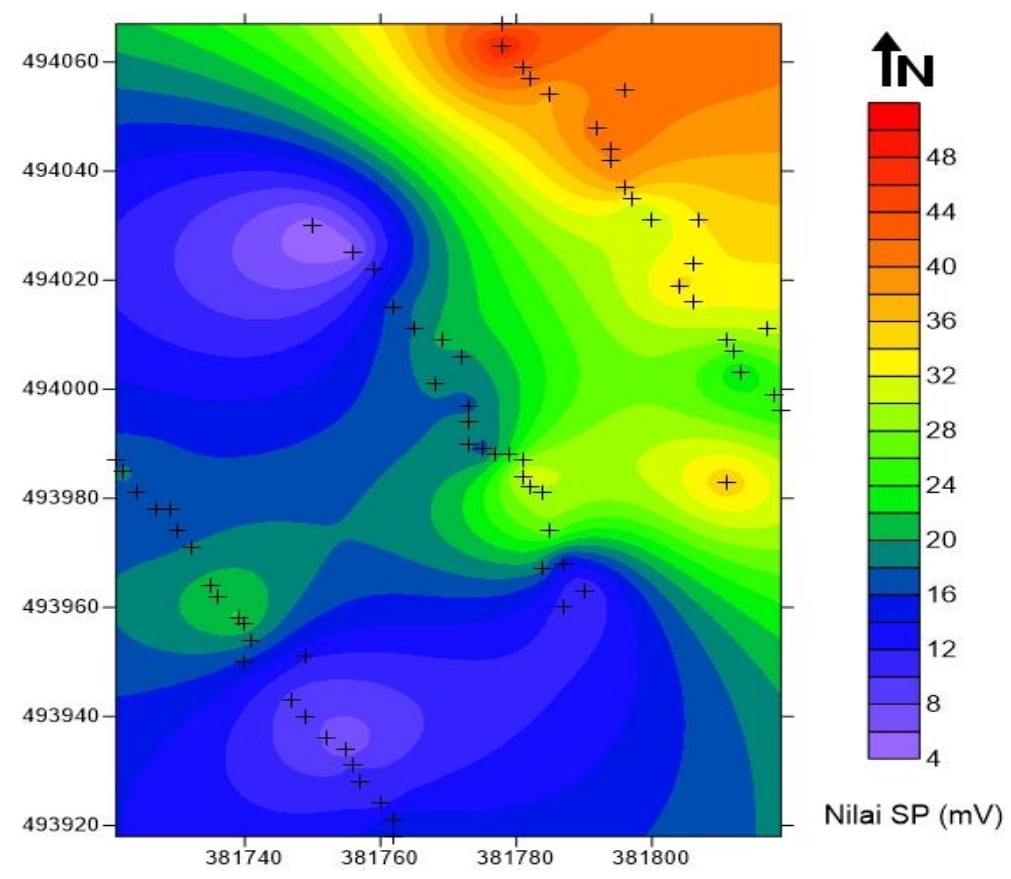

Gambar 7. Peta Kontur Isopotensial Bulan Agustus

Gambar 3 menunjukkan hasil pengukuran di lintasan 1 , pada grafik tersebut terlihat hasil pengukuran di bulan pertama dominan lebih tinggi daripada bulan kedua. Namun pada bulan kedua tidak ada lagi terdapat nilai negatif. Nilai SP terukur pada bulan kesatu berkisar -18,9 - 43,6 $\mathrm{mV}$, bulan kedua pengukuran diperoleh nilai antara 3,2-26 mV.

Hasil pengukuran di lintasan 2 ditunjukkan oleh Gambar 4. Nilai SP pada pengukuran bulan pertama berkisar $-3,3-37,8$ $\mathrm{mV}$, sedangkan pada bulan kedua nilai SP yang terukur $-3,8-36,8 \mathrm{mV}$. Dilihat dari grafik tersebut terlihat nilai SP pada bulan kedua cenderung lebih tinggi daripada pengukuran dibulan pertama. Hal tersebut dapat diperkirakan akibat dari curah hujan yang sering terjadi di akhir bulan Juli menjelang bulan Agustus.

Sama halnya seperti pengukuran pada lintasan 3 yang ditunjukkan oleh Gambar 5, nilai SP pada bulan kedua cenderung lebih tinggi dibandingkan pengukuran pada bulan pertama. Nilai potensial diri yang terukur pada bulan pertama berkisar antara 3,9-28,6 mV, dan nilai potensial yang terukur pada bulan kedua yaitu berkisar 17,5 - 60,6 mV. Meningkatnya nilai SP yang terukur pada awal bulan Agustus juga dapat diperkirakan akibat dari curah hujan yang sering terjadi di Kota Langsa dan sekitarnya.

Nilai beda potensial listrik alami yang terukur di lapangan selanjutnya dikoreksi dan diolah menggunakan Surfer 13 untuk memperoleh peta kontur isopotensial pada saat pengukuran di bulan pertama dan bulan kedua. Hasil pengolahan data berupa kontur isopotensial ditunjukkan pada gambar 6 dan 7 .

Distribusi nilai potensial yang terukur pada bulan pertama akuisisi data lapangan berdasarkan peta kontur isopotensial yang ditunjukkan oleh Gambar. 6. Skala nilai SP yang terukur $0 \mathrm{mV}$ sampai $46 \mathrm{mV}$. Dari gambar tersebut, terlihat bahwa potensial relatif tinggi berada pada pengukuran di lintasan 1 dan lintasan 3. Dapat diasumsikan bahwa di daerah yang memiliki potensial listrik yang relatif tinggi memiliki potensi air tanah yang cenderung lebih banyak dibandingkan daerah 
yang potensial listriknya rendah, seperti pada lintasan 2.

Pada Agustus atau bulan kedua akuisisi data lapangan terlihat pola sebaran nilai potensial berubah berkisar dari $4-52 \mathrm{mV}$ seperti yang terlihat pada Gambar 7. Potensial listrik yang relatif tinggi tersebar di bagian Timur Laut lokasi penelitian atau lintasan 3, dan potensial listrik menurun ke bagian Barat Daya atau lintasan 1. Potensial tinggi mengindikasikan wilayah tersebut termasuk zona konduktif, dimana dalam peta kontur zona konduktif tersebut berkisar 20-50 mV. Nilai potensial yang terukur termasuk dalam kategori potensial alami yang disebabkan oleh adanya pergerakan air bawah tanah.

Perbandingan kedua peta kontur isopotensial diatas menunjukkan perubahan nilai potensial yang terukur pada dua bulan pengukuran. Terlihat pada pengukuran di bulan Agustus, nilai potensial pada lintasan 1 dan 2 relatif mengalami penurunan dibandingkan bulan sebelumnya (Juli). Namun pada lintasan 3 , nilai SP terukur cenderung lebih tinggi pada bulan Agustus daripada bulan Juli.

Berdasarkan nilai potensial pada kedua peta kontur diatas maka terlihat adanya perubahan nilai SP dari bulan pertama dan bulan kedua pengukuran. Hal ini mengindikasikan bahwa perubahan nilai potensial alami tersebut diakibatkan dari adanya perubahan potensi air tanah. Berubahnya potensi air tanah mengarah kepada pengurangan jumlah air tanah. Pengurangan air ini disebabkan oleh adanya aktivitas pengambilan air tanah yang berlebihan setiap harinya, sehingga dapat diyakini mengakibatkan berkurangnya jumlah air tanah pada lapisan akuifer. Jika hal ini terus terjadi bahkan terus mengalami pengurangan jumlah air tanah dikhawatirkan kawasan tersebut akan berpotensi mengalami penurunan muka tanah semakin cepat [4].

\section{SIMPULAN DAN SARAN Simpulan}

Dari hasil penelitian yang dilakukan dapat disimpulkan bahwa potensi air yang diamati dari waktu yang berbeda ini dimanfaatkan untuk memprediksi terjadinya penurunan muka tanah (land subsidence) di Desa Lengkong. Bulan kedua pengukuran terdapat perubahan nilai potensial yaitu menjadi lebih rendah dari bulan sebelumnya. Rendahnya nilai potensial yang terukur menandakan bahwa adanya perubahan jumlah air dalam akuifer menjadi lebih sedikit dari sebelumnya. Jika jumlah air tanah dalam akuifer terus berkurang maka daya dukung tanah menjadi semakin melemah dan potensi bencana land subsidence akan semakin cepat terjadi.

\section{Saran}

Identifikasi bencana penurunan muka tanah di Gampong Lengkong sebaiknya rutin dilakukan, tidak hanya menggunakan metode geofisika yang sederhana namun juga dengan metode yang lainnya yang lebih baik dan akurat.

\section{UCAPAN TERIMA KASIH}

Terima kasih kepada LPPM Universitas Samudra yang telah mendanai kegiatan penelitian ini melalui Program Penelitian Dosen Muda (PDM) Tahun 2019.

\section{DAFTAR PUSTAKA}

[1] Google Maps, "Gampong Lengkong, Kota Langsa, Aceh, Indonesia,” 2019. [Online]. Available:

https://www.google.co.id/maps/@4.46414 44,97.9336081,216a, 35y,359.53h, 57.28t/d ata $=! 3 \mathrm{~m} 1$ !1e3 . [Accessed: 16-Aug-2019].

[2] Handoko, A. W., Darsono, dan Darmanto, 2016, Aplikasi Metode Self Potential untuk Pemetaan Sebaran Lindi di Wilayah Tempat Pembuangan Akhir (TPA) Putri Cempo Surakarta, Indonesian Journal of Applied. Physics, Vol. 6, No. 01, pp. 1322.

[3] Hiskiawan, P., 2016, Agrogeofisika Metode Self Potential Guna Evaluasi 
Lahan Perkebunan Tebu, J. Pendidik. Fis. dan Keilmuan, Vol. 2, No. 1, p. 36.

[4] Pryambodo, D. G., dan Supriyadi, 2015, Zonasi Penurunan Muka Air Tanah Di Wilayah Pesisir Berdasarkan Teknik Geofisika Gayaberat Mikro 4D (Studi Kasus: Daerah Industri Kaligawe Semarang), Jurnal Kelautan Nasional, Vol. 10, No. 3, pp. 151-162.

[5] Tribunnews, 2018, Gampong Lengkong Masuk Kawasan Lindung Geologi Serambi Indonesia [Online]. Available: https://aceh.tribunnews.com/2018/02/19/g ampong-lengkong-masuk-kawasan-

lindung-geologi. [Accessed: 13-Feb2019]. 